\title{
Аналіз потреби у фізичній реабілітації учасників АТО та тактика відновлення військових з ураженням суглобів
}

\author{
удк: 796-085:616-001.45 \\ С. О. Грін, О. Д. Остроушко
}

Український державний медико-соціальний центр ветеранів війни, с. Циблі, Київська область, Україна

\begin{abstract}
Резюме. Мета. Досліджено особливості застосування фізично-реабілітаційних заходів для осіб з вогнепальними і травматичними ураженнями суглобів кінцівок на базі Українського державного медико-соціального центру ветеранів війни. Методи. Узагальнено інформацію 3 20 областей України щодо потреби у фізичній реабілітації серед демобілізованих учасників АTO з ураженням суглобів верхньої і нижньої кінцівок та встановлено відсоткове співвідношення осіб з інвалідністю. Результати. Проведене дослідження відображає кількісне превалювання вогнепальних уражень нижньої кінцівки, а саме колінного і надп'ятково-гомілкового суглобів; найменша кількість поранених має ураження кульшового суглоба. Серед вогнепальних уражень верхньої кінцівки на першому місці - поранення плечового суглоба, далі ураження променево-зап'ясткового і найменше ліктьового суглоба. Розроблено картку фізичнореабілітаційного обстеження для пацієнтів з порушеннями опорно-рухового апарату, яка відображає показники антропометрії, гоніометрії, силові показники, а також результати функціональних проб і тестів та вираженість больового синдрому. Запроваджена оцінкова картка дозволяє визначити початковий рівень функціонального стану пацієнта та висвітлити результати проведеної програми фізичної реабілітації. Наведено середньостатистичні показники покращення функціонального стану суглобів верхньої та нижньої кінцівок після проведеного курсу фізичної реабілітації.

Ключові слова: фізична реабілітація, учасники АТО, ураження суглобів.
\end{abstract}

\section{Анализ необходимости в физической реабилитации участников АТО и тактика восстановления военнослужащих с поражением суставов С. А. Грин, А. Д. Остроушко}

Резюме. Цель. Исследованы особенности применения реабилитационных мероприятий для лиц с огнестрельными и травматическими поражениями суставов конечностей на базе Украинского государственного медико-социального центра ветеранов войны. Методы. Обобщена информация из 20 областей Украины о необходимости в физической реабилитации демобилизованных участников АТО с поражением суставов верхней и нижней конечностей и установлено процентное соотношение лиц с инвалидностью. Результаты. Проведенное исследование отражает количественное преобладание огнестрельных поражений нижних конечностей, а именно коленного и голеностопного суставов, наименьшее количество раненых имеет поражение тазобедренного сустава. Среди огнестрельных поражений верхней конечности на первом месте - ранения плечевого сустава, далее поражения лучезапястного и меньше - локтевого сустава. Разработана карта реабилитационного обследования пациентов с нарушениями опорно-двигательного аппарата, отражающая показатели антропометрии, гониометрии, силовые показатели, а также результаты функциональных проб и тестов и выраженность болевого синдрома. Введенная оценочная карта позволяет определить начальный уровень функционального состояния пациента и осветить результаты проведенной программы физической реабилитации. Представлены среднестатистические показатели улучшения функционального состояния суставов верхней и нижней конечностей после проведенного курса физической реабилитации.

Ключевые слова: физическая реабилитация, участники АТО, поражение суставов.

Analysis of necessity in physical rehabilitation of ATO participants and tactics of reconstruction of military servants with the damage of joins

S. O. Hrin, O. D. Ostroushko

Abstract. Objective. The features of physical and rehabilitation measures application for persons with gunshot and traumatic lesions of extremity joints on the basis of the Ukrainian State Medical and So- 
cial Center of War Veterans have been studied. Methods. The information from 20 regions of Ukraine regarding the need for physical rehabilitation among demobilized ATO participants with upper and lower extremity lesions have been summarized, the percentage of persons with disabilities have been determined. Results. Conducted research reflects the quantitative prevalence of gunshot lesions of the lower extremity, namely the knee and ankle joint, the smallest number of wounded have lesions of the hip joint. Among the gunshot lesions of the upper extremity the greatest percentage constitutes the wounds of the shoulder joint, followed by damage to the radial wrist and elbow joint. A card for physical and rehabilitation examination for patients with locomotorium disorders has been developed, which reflects anthropometry, goniometry, strength indices, as well as results of functional tests, and severity of pain syndrome. Introduced assessment card allows to determine the initial level of patient functional state and highlight the outcomes of physical rehabilitation program. The overall averages of improving the functional state of the upper and lower extremity joints after the course of physical rehabilitation are presented. Keywords: physical rehabilitation, ATO participants, joint lesions.

\section{Аналіз літературних даних та постановка} проблеми. Стан неоголошеної війни в Україні потребує вироблення практики проведення комплексу фрізично-реабілітаційних заходів щодо відновлення здоров'я та працездатності поранених із вогнепальними та травматичними ураженнями різних ступенів важкості.

Фізична реабілітація (ФР) - це багатоланковий процес відновлення здоров'я людини та реінтеграція ії̈ в профресійне та соціальне життя [11]. Процес ФР, який визначається поєднанням фрізіологічноанатомічних, суто медичних знань і навичок у галузі теорії та методики фрізичної культури, $є$ одним із напрямів, методологія та практична методика якого потребують активного розвитку у зв'язку із завданнями, поставленими сьогоденням [3].

Проблеми реабілітації хворого складні і залежать від командної взаємодії багатьох фрахівців - терапевтів, хірургів, травматологів, фрізіотерапевтів, психологів, психіатрів та фахівців 3 фрізичної реабілітації. Надане лікувальне відновлення повинно бути адекватним фрізичному і психічному стану пацієнта на окремих етапах реабілітації [2].

За інфрормацією в 3 МІ з посиланням на Генеральний штаб України, статус учасника Антитерористичної операції (далі - АТО) отримали близько 121 тис. військовослужбовців, які потребують медичної, психологічної та фрізичної реабілітації.

За даними медичного департаменту Міністерства Оборони України за період проходження АТО з 2014 по 2016 рр. в Збройних Силах України поранення отримали близько 9 тис. військових, із них вогнепальні поранення м'яких тканин становлять $60 \%$, вогнепальні переломи кінцівок - $40 \%$.

У другій Ліванській війні $44 \%$ усіх уражень представлені травмами кінцівок [14]. Приблизно такі ж дані спостерігались у секторі Газа в 2009 р. [15]. Висока частота уражень кінцівок передусім пов'язана з найменшою захищеністю цих ділянок тіла сучасного солдата, в той час як тулуб захищають бронежилети, а голову - каски із надміцних матеріалів, що набагато зменшило відсоток постраждалих з ураженнями названих структур. Це також підтверджується шляхом порівняння зразка травм, отриманих у війні в Іраку американськими (високий відсоток травматизації кінцівок) та іракськими (високий коефріцієнт ушкоджень тулуба і голови) солдатами за рахунок неналежного екіпірування іракських військовослужбовців [10]. В екстремальних умовах військовослужбовці отримують не тільки вогнепальні ураження, спостерігається велика кількість травматичних уражень, зокрема колінного та надп'ятково-гомілкового суглобів. Цьому сприяє збільшення навантаження на суглоби нижніх кінцівок насамперед за рахунок ваги амуніції.

Особи, які отримали вогнепальні та травматичні ураження в зоні проведення АТО, потребують висококваліфрікованої реабілітаційної допомоги. Відповідно до Указу Президента України від 14 листопада 2014 року № 880/2014 «Про Рішення Ради національної безпеки і оборони України від 4 листопада 2014 року», Доручення Секретаріату Кабінету Міністрів України від 24.11.2014 р. № 42513/1/1-14 щодо виконання пункту 9 Протокольного рішення Адміністрації Президента України стосовно соціальної реабілітації учасників Антитерористичної операції на Сході України та протезування осіб, постраждалих під час АТО, реабілітація учасників АТО проводиться в госпіталях та санаторіях ветеранів війни. Відновне лікування хворих з бойовими ураженнями на базі військового санаторію пов'язано зі сприятливою дією на організм хворих природних курортних і префрормованих фрізичних фракторів, які сприяють прискоренню процесів загоєння ран і консолідації переломів [10].

Сутність методів і засобів ФР полягає у багаторазовому, систематично повторюваному та поступово збільшуваному тренуванні, що викликає в організмі людини позитивні функціональні, а 
часом і структурні зміни [9]. Внаслідок цього механізми регуляції нормалізуються, підвищуються можливості адаптації організму хворого до динамічно мінливих умов середовища [4]. 3 одного боку, оформлюються і зміцнюються нові або вдосконалюються наявні рухові навички, з іншого - розвиваються та удосконалюються ті можливості людини (сила, витривалість, швидкість, гнучкість, спритність), що визначають фрізичну працездатність організму. Жодні інші засоби і методи реабілітації не в змозі замінити фрізичні вправи [5].

Реабілітація військових в Україні проводиться як у державних установах, так і в комерційних закладах на волонтерських засадах, які забезпечені необхідним обладнанням, устаткуванням тощо для надання реабілітаційних послуг.

Український державний медико-соціальний центр ветеранів війни (УДМСЦВВ) - головний координаційний центр серед 29 госпіталів ветеранів війни, на базі якого було розроблено комплекс заходів з ФР учасників АТО для відновлення функціональних показників суглобів верхньої і нижньої кінцівок.

Зв'язок теми 3 науковими чи практичними завданнями. Вивчення питання узгоджено із науково-дослідною роботою кафедри фрізичної реабілітації НУФВСУ «Організація та методичні особливості фрізичної реабілітації осіб з вогнепальними та мінно-вибуховими ураженнями» (номер держреєстрації 0116U001667, шисрр 4.8).

Мета дослідження - аналіз особливостей застосування фізично-реабілітаційних заходів для осіб із вогнепальними і травматичними ураженнями суглобів кінцівок на базі УДМСЦВВ.

Реалізація цієї мети вимагає вирішення завдань:

- узагальнити інформацію щодо потреби учасників АТО з ураженням суглобів верхньої та нижньої кінцівок у ФР;

- визначити структуру діяльності відділення $\Phi P ;$

- проаналізувати тактику відновлювальної терапії для осіб із зазначеною патологією.

Методи дослідження: збирання й узагальнення даних щодо потреби у фізичній реабілітації учасників АТО з 20 областей України. Було використано такі методи:

- спостереження - формальне (інфрормований пацієнт) та нефрормальне (неінформований пацієнт) [7];

- суб'єктивна оцінка - визначення основних скарг пацієнта та їх зв'язок з руховою активністю; наявність больових відчуттів оцінювали за допомогою візуально-аналогової шкали болю (ВАШ) [1];

- гоніометрія - вимірювання рухливості в суглобах за допомогою гоніометрів [13];

- мануально-м'язове тестуВання (ММT) за шестирозрядною міжнародною системою; передбачає для кожного м'яза чи м'язової групи визначення специфрічного руху, що називається «тестовим рухом» [13];

- антропометричні ВимірюВання обхватних розмірів і довжини кінцівки сантиметровою стрічкою;

- фуннкціональні проби, рухові тести, динамометрія (тест хворої руки, тест Яргезона, тест передньої і задньої «висувної шухляди», верхня і нижня проби Мінгаццині-Барре, шкала Берга та ін.) дозволяють оцінити слабкість м'язів кінцівки, здатність до виконання побутових операцій, стійкість стояння та рівновагу, функціональні критерії ходьби $[1,6]$.

Дослідження проведено на базі УДМСЦВВ з листопада 2016 (початок дослідження) по квітень 2017 р. (його завершення). Дослідження здійснювали з дотриманням принципів біоетики.

Результати дослідження та їх обговорення. Зважаючи на те що УДМСЦВВ $є$ головним координаційним центром серед 29 госпіталів ветеранів війни, на базі цього центру в жовтні 2016 р. було зібрано, проаналізовано та узагальнено інформацію з 20 областей України щодо потреби у ФР серед демобілізованих учасників АТО з ураженням суглобів верхньої і нижньої кінцівок, що відображено в таблиці 1.

Комітет експертів 3 медичної реабілітації ВООЗ наголосив, що «Реабілітація - це процес, метою якого $\epsilon$ запобігання інвалідності під час лікування захворювань і допомога хворому у досягненні максимальної фрізичної, психічної, профресійної, соціальної та економічної повноцінності, на яку він буде здатний у межах існуючого захворювання» [12].

Нами узагальнено інформацію щодо статусу інвалідності у демобілізованих учасників АТО 3 ушкодженням суглобів (табл. 2). У відсотковому відношенні ці дані наведено на рисунку 1.

Значна частина заходів щодо запобігання інвалідності та з реабілітації проводитиметься у санаторно-курортних умовах із використанням природних і лікувальних ресурсів з метою збільшення реабілітаційного та санаторно-курортного потенціалу України [10].

Зважаючи на те, що при ураженнях верхньої кінцівки найчастіше спостерігається пошкодження плечового суглоба, а нижньої кінцівки - колінного та надп'ятково-гомілкового суглобів, 
Спортивна медицина і фізична реабілітація, № 1, 2018

ТАБЛИЦЯ 1 - Потреба у ФР демобілізованих учасників АТО з ушкодженням суглобів (жовтень 2016 р.)

\begin{tabular}{|c|c|c|c|c|c|c|c|c|}
\hline № 3/n & Область & $\Pi$ & л & п3 & Ку & к & HГ & Усьoro \\
\hline 1 & Вінницька & 31 & 10 & 18 & 11 & 50 & 32 & 152 \\
\hline 2 & Волинська & 9 & 5 & 11 & 0 & 11 & 17 & 53 \\
\hline 3 & Донецька & 2 & 0 & 0 & 1 & 1 & 2 & 6 \\
\hline 4 & Дніпропетровська & 21 & 12 & 11 & 14 & 33 & 13 & 104 \\
\hline 5 & Житомирська & 7 & 5 & 8 & 11 & 13 & 12 & 56 \\
\hline 6 & Закарпатська & 15 & 7 & 5 & 10 & 30 & 12 & 79 \\
\hline 7 & Запорізька & 23 & 21 & 19 & 16 & 20 & 18 & 117 \\
\hline 8 & Київська & 48 & 23 & 25 & 21 & 55 & 71 & 243 \\
\hline 9 & Кіровоградська & 5 & 3 & 6 & 7 & 11 & 7 & 39 \\
\hline 10 & Львівська & 28 & 14 & 22 & 36 & 48 & 30 & 178 \\
\hline 11 & Одеська & 1 & 2 & 1 & 4 & 9 & 4 & 21 \\
\hline 12 & Полтавська & 7 & 3 & 4 & 3 & 9 & 6 & 32 \\
\hline 13 & Рівненська & 10 & 5 & 7 & 8 & 20 & 17 & 67 \\
\hline 14 & Сумська & 6 & 2 & 6 & 4 & 8 & 16 & 42 \\
\hline 15 & Харківська & 3 & 2 & 2 & 1 & 12 & 7 & 27 \\
\hline 16 & Херсонська & 8 & 4 & 12 & 5 & 22 & 10 & 61 \\
\hline 17 & Хмельницька & 4 & 0 & 3 & 7 & 15 & 8 & 37 \\
\hline 18 & Черкаська & 14 & 9 & 6 & 25 & 23 & 20 & 97 \\
\hline 19 & Чернівецька & 4 & 4 & 10 & 2 & 12 & 8 & 40 \\
\hline \multirow[t]{2}{*}{20} & Чернігівська & 9 & 10 & 4 & 7 & 21 & 16 & 67 \\
\hline & Усього & 255 & 141 & 180 & 193 & 423 & 326 & 1518 \\
\hline
\end{tabular}

Примітка: П - плечовий суглоб; Л - ліктьовий суглоб; ПЗ - променево-зап`ястковий суглоб, Ку - кульшовий суглоб, К - колінний суглоб, НГ - надп'ятково-гомілковий суглоб.

ТАБЛИЦЯ 2 - Розподіл ушкоджень суглобів у демобілізованих учасників АТО, які мають інвалідність

\begin{tabular}{|l|c|c|c|c|c|c|c|}
\hline & П & Л & Пз & Ку & К & нП & Усього \\
\hline Всього & 255 & 141 & 180 & 193 & 423 & 326 & 1518 \\
Із них з інвалідністю & 75 & 49 & 68 & 85 & 117 & 118 & 512 \\
\hline
\end{tabular}

варто звернути особливу увагу саме на ці групи пацієнтів з метою запобігання інвалідності.

Починаючи з листопада 2016 р., щомісяця в УДМСЦВВ поступає 45 осіб, які потребують проходження курсу ФР після вогнепальних або травматичних уражень великих суглобів. За період 3 листопада 2016 по квітень 2017 р. курс ФР пройшли 270 осіб (табл. 3).
Процес ФР ґрунтується на базових принципах, одним з яких $€$ індивідуальний підхід. Його дотримання неможливо без визначення функціональних можливостей певної особи. Тому, як і в іншій галузі, що опікується проблемами здоров'я людини, у сорері ФР існує необхідність збирання інфрормації про початковий рівень порушень рухових можливостей та їх динаміку в особи, яка

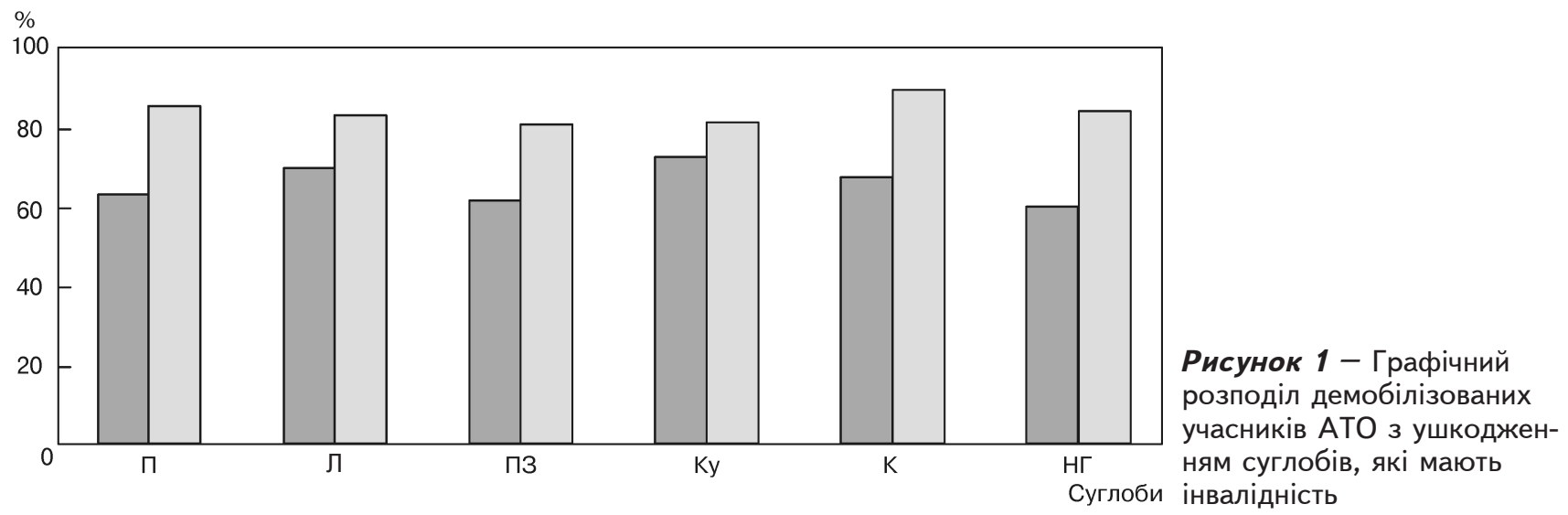


ТАБЛИЦЯ 3 - Розподіл учасників АТО з ураженням суглобів, які пройшли курс ФР в УДМСЦВВ (листопад 2016-квітень 2017 p.)

\begin{tabular}{|c|c|c|c|c|c|c|c|c|}
\hline № $3 / n$ & Область & $\Pi$ & л & $\Pi 3$ & Ку & $\kappa$ & нП & Усього \\
\hline 1 & Вінницька & 5 & 1 & 2 & 1 & 4 & 5 & 18 \\
\hline 2 & Волинська & 1 & 1 & 1 & 0 & 1 & 2 & 6 \\
\hline 3 & Донецька & 2 & 0 & 0 & 1 & 1 & 2 & 6 \\
\hline 4 & Дніпропетровська & 4 & 3 & 1 & 2 & 5 & 3 & 18 \\
\hline 5 & Житомирська & 3 & 1 & 3 & 3 & 5 & 3 & 18 \\
\hline 6 & Закарпатська & 1 & 0 & 1 & 1 & 1 & 2 & 6 \\
\hline 7 & Запорізька & 3 & 3 & 1 & 1 & 1 & 3 & 12 \\
\hline 8 & Київська & 8 & 5 & 5 & 4 & 6 & 8 & 36 \\
\hline 9 & Кіровоградська & 3 & 1 & 2 & 3 & 5 & 4 & 18 \\
\hline 10 & Львівська & 5 & 4 & 5 & 5 & 5 & 6 & 30 \\
\hline 11 & Одеська & 1 & 1 & 0 & 0 & 2 & 2 & 6 \\
\hline 12 & Полтавська & 2 & 0 & 1 & 0 & 2 & 1 & 6 \\
\hline 13 & Рівненська & 1 & 0 & 1 & 1 & 1 & 2 & 6 \\
\hline 14 & Сумська & 2 & 1 & 2 & 1 & 2 & 4 & 12 \\
\hline 15 & Харківська & 1 & 1 & 1 & 1 & 4 & 4 & 12 \\
\hline 16 & Херсонська & 1 & 1 & 1 & 0 & 2 & 1 & 6 \\
\hline 17 & Хмельницька & 2 & 0 & 1 & 1 & 5 & 3 & 12 \\
\hline 18 & Черкаська & 3 & 2 & 1 & 4 & 4 & 4 & 18 \\
\hline 19 & Чернівецька & 1 & 0 & 2 & 0 & 2 & 1 & 6 \\
\hline \multirow{2}{*}{20} & Чернігівська & 2 & 3 & 1 & 2 & 5 & 5 & 18 \\
\hline & Усього & 51 & 28 & 32 & 31 & 63 & 65 & 270 \\
\hline
\end{tabular}

виступає суб'єктом реабілітаційного процесу [7, 13].

Проведення обстеження рухових фрункцій дозволяє фахівцю з ФР сформувати уявлення про певний руховий потенціал, планувати і коригувати реабілітаційний процес, визначати ефективність проведеної програми ФР [8].

Нами розроблено картку пацієнта з порушеннями опорно-рухового апарату, яка дозволяє оцінити показники фрункціональних можливостей в осіб з ураженням суглобів (рис. 2).

Комплекс заходів ФР складається з кінезитерапії, масажу, фрізіотерапії, механотерапії, ерготерапії у різноманітних поєднаннях.

У відділенні ФР УДМСЦВВ застосовують такі засоби та методики:

- кінезитерапія: стабілізація суглоба, постізометрична релаксація, пропріорецептивна нейром'язова фасилітація, суглобова гра, фрізичні вправи лікувальної гімнастики (пасивні вправи, вправи на протидію опору, активні вправи з навантаженням тощо);

- масаж: періостальний, сегментарно-рефлекторний, лімфо-дренажний, точковий, апаратний;

- фозіотерапевтичні процедури: електротерапія (електрофорез лікарських речовин, електроміостимуляція, дарсонвалізація), світлолікування (ультрафріолетове й інфррачервоне опромінення), гідротерапія (ванни з додаванням лікарських речовин або ефрірних олій, місцеві 4-камерні ванни, підводний душ-масаж), теплолікування (грязе-, парафріно- і озокеритолікування), ультразвукова терапія, магнітотерапія. Методи фрізіотерапії підбирають з урахуванням місцевого ранового процесу і періоду реабілітації;

- механотерапія: апарати ARTROMOT для кожного суглоба верхньої та нижньої кінцівок (S3, E2, H, F, K1, SP3), тренажери для стопи та надп'ятково-гомілкового суглоба (тренажер «Relax Medical Systems», простий педальний тренажер, апарат «Draco Terma»), тренажери для плечового суглоба (гнучкий вібротренажер «Flaxibar», вібраційна платформа «ViaGym», плечовий блок «Thera-band»), кардіотренажери (степпери «MaxxPro», велотренажери «ChristopeitSport CPS40» та «Kettler topas», орбітрек «Evrotop», бігова доріжка «InterAtletika»), силові тренажери («Infiniti fitness system», «Vasil», «InterAtletika»; ВТ217 - машина Смітта з противагою, ВТ122 трицепс-машина, ВТ130 - блокова рамка одинарна, ВТ106 - біцепс-машина), стіл для тракційної терапії TRITON DTS TRT-600;

- ерготерапія.

В результаті аналізу ефективності реабілітаційних втручань у пацієнтів з ураженням суглобів верхньої і нижньої кінцівок було виявлено поліпшення функціональних показників відповідно до 


\begin{tabular}{|c|c|c|c|c|c|c|c|c|c|c|}
\hline \multirow{2}{*}{\multicolumn{11}{|c|}{$\begin{array}{l}\text { П.І.Б. пацієнта_—— рік народження } 1982 \\
\text { Контакти }\end{array}$}} \\
\hline & & & & & & & & & & \\
\hline \multirow{2}{*}{\multicolumn{11}{|c|}{$\begin{array}{l}\text { Дата поступлення / виписки } 06.12 .16 / 29.12 .16 \\
\text { Діагноз МВТ. Наслідки кульового наскрізного } \\
\text { поранення лівого надп'ятково-гомілкового суглоба }\end{array}$}} \\
\hline & & & & & & & & & & \\
\hline \multicolumn{11}{|c|}{$\begin{array}{l}\text { Короткий анамнез; проведене лікування Поранення } \\
\text { отримано 18.09.2016 } \\
\end{array}$} \\
\hline \multirow{3}{*}{\multicolumn{11}{|c|}{ 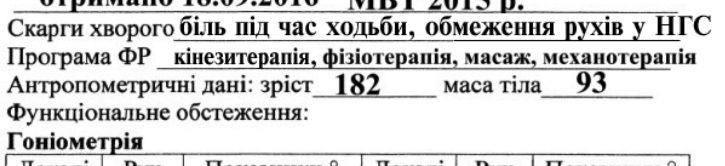 }} \\
\hline & & & & & & & & & & \\
\hline & & \multirow[t]{2}{*}{ Pyx } & \multicolumn{2}{|c|}{ Показники $^{\circ}$} & \multirow{2}{*}{\multicolumn{2}{|c|}{\begin{tabular}{c|} 
Локалі \\
зація
\end{tabular}}} & \multirow[t]{2}{*}{ Pyx } & \multicolumn{3}{|c|}{ Показники $^{\circ}$} \\
\hline \multicolumn{2}{|c|}{\begin{tabular}{|c|} 
Локалі \\
зація \\
\end{tabular}} & & \begin{tabular}{l|l} 
до & $\mathrm{r}$ \\
\end{tabular} & після & & & & до & піс & \\
\hline Лівий & & $\mathbf{D}$ & 30 & 40 & Ліви & & $\mathbf{D}$ & 31 & 40 & \\
\hline НГC & & $\mathbf{P}$ & 20 & 40 & НГС & & $\mathbf{P}$ & 23 & 40 & \\
\hline \multirow{2}{*}{\multicolumn{2}{|c|}{ актив. }} & $\mathbf{E}$ & 15 & 20 & паси & & E & 16 & 20 & \\
\hline & & $\mathbf{I}$ & 20 & 33 & & & L & 25 & 35 & \\
\hline \multirow{2}{*}{\multicolumn{11}{|c|}{ Мануально-м'язове тестування Динамометрія кистьова }} \\
\hline & & & & & & & & & & \\
\hline \multirow[t]{3}{*}{ М'яз } & \multirow{2}{*}{\multicolumn{2}{|c|}{$\begin{array}{l}\text { Оцінка } \\
\text { (бали) }\end{array}$}} & \multirow[t]{3}{*}{ М'яз } & \multirow{2}{*}{\multicolumn{2}{|c|}{$\begin{array}{l}\text { Оцінка } \\
\text { (бали) }\end{array}$}} & & & \multicolumn{3}{|c|}{ ДМК (кг) } \\
\hline & & & & & & & & до & \multicolumn{2}{|c|}{ після } \\
\hline & до & після & & до & після & \multicolumn{2}{|c|}{ Права } & & & \\
\hline $\mathbf{B} / \mathbf{\Gamma}$ & 3 & 4 & & & . & & ва & & & \\
\hline $\mathbf{M} / \mathbf{\Gamma}$ & 3 & 4 & & & & \multicolumn{5}{|c|}{ Обхватні виміри } \\
\hline Лит. & 3 & 5 & & & & \multirow{2}{*}{\multicolumn{3}{|c|}{ Локалізація }} & \multicolumn{2}{|c|}{$\begin{array}{l}\text { Показники } \\
\text { (см) }\end{array}$} \\
\hline \multirow{2}{*}{ камб. } & & & & & & & & & & після \\
\hline & & 5 & & & & \multicolumn{4}{|c|}{ c/3 гом. J 36,7} & 37.5 \\
\hline & & & & & & & 3 roN & I. I & 39 & 39 \\
\hline
\end{tabular}

Показники функціональних проб і тестів

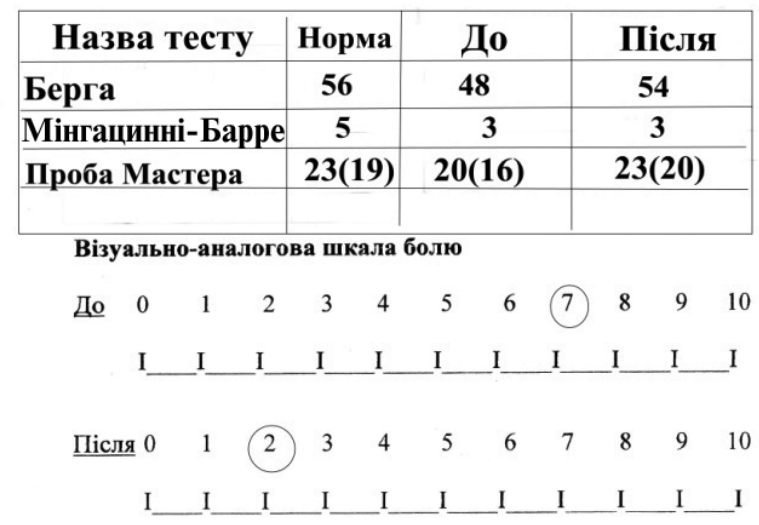

Результати ФР Покращено гоніометричні показники, збільшено силу м'язів, знижено больові відчуття. Зменшено час на відновлення після навантаження Покращено стійкість стояння, рівновагу

Рекомендації Продовжити заняття в домашніх умовах відповідно до індивідуальної програми реабілітації

Фахівець з ФР П Підпис

Рисунок 2 - Приклад картки пацієнта з порушеннями опорно-рухового апарату:

в/г - великогомілковий м'яз; м/г - малогомілковий; лит. - литковий м'яз; камб. - камбалоподібний м'яз

норми (норма - 100 \%). На рисунку 3 наведено гоніометричні показники, на рисунку 4 відображено показники ММТ з урахуванням вихідного рівня функціональних можливостей.

Результати ффункціональних проб і тестів не було узагальнено. Підбір певної методики тестування базувався на принципі індивідуального підходу.

Всі пацієнти, які пройшли курс ФР, відзначили зменшення або зникнення проявів болю, що реєструвалося за допомогою ВАШ болю.

Висновки. Основна мета реабілітації - повернення хворих та інвалідів до побутових і трудових процесів, у суспільство та сім'ю, відновлення особистісних можливостей людини як повноправного члена суспільства.

Згідно з інформацією, яку було узагальнено в УДМСЦВВ в жовтні 2016 р., щодо необхідності у ФР демобілізованих учасників АТО з ураженнями суглобів верхньої і нижньої кінцівок, 1518 осіб потребують фрізично-реабілітаційних втручань.

У відділені ФР УДМСЦВВ розроблено комплексну програму ФР для пацієнтів з ураженням суглобів, яка базується на поєднанні вже добре відомих засобів ФР із сучасними реабілітаційними методиками та технологіями, ефеективність якої відображено на рисунках 3 та 4. Такий комплексний підхід надав змогу скоротити терміни реабілітації, про що свідчать результати рентгенологічних досліджень, реовазографії судин кінцівок, показники функціональних проб і тестів.

Застосування засобів фрізичної реабілітації для поранених військовослужбовців дозволяє якісно відновити функціональний стан організму та адаптаційні резерви, нормалізувати емоційну, моральну і мотиваційну сфери особистості, досягти оптимального рівня особистої адаптації та професійно важливих якостей військовослужбовця, забезпечити його військово-професійну працездатність.

Фізична реабілітація $є$ гостро необхідною також тоді, коли поранення було настільки важким, що повноцінне відновлення неможливе. У такому випадку ФР забезпечить досягнення i підтримання оптимального фрізичного стану, а також допоможе набути необхідних навичок для подальшого життя.

Перспективи подальших досліджень полягають у подальшому розширенні дослідження на клінічних базах з метою оцінки ефективності застосування програми ФР, складовими якої $\epsilon$ традиційні засоби і методи та сучасні технології ФР для відновлення здоров'я та працездатності осіб з наслідками вогнепальних уражень кінцівок. 


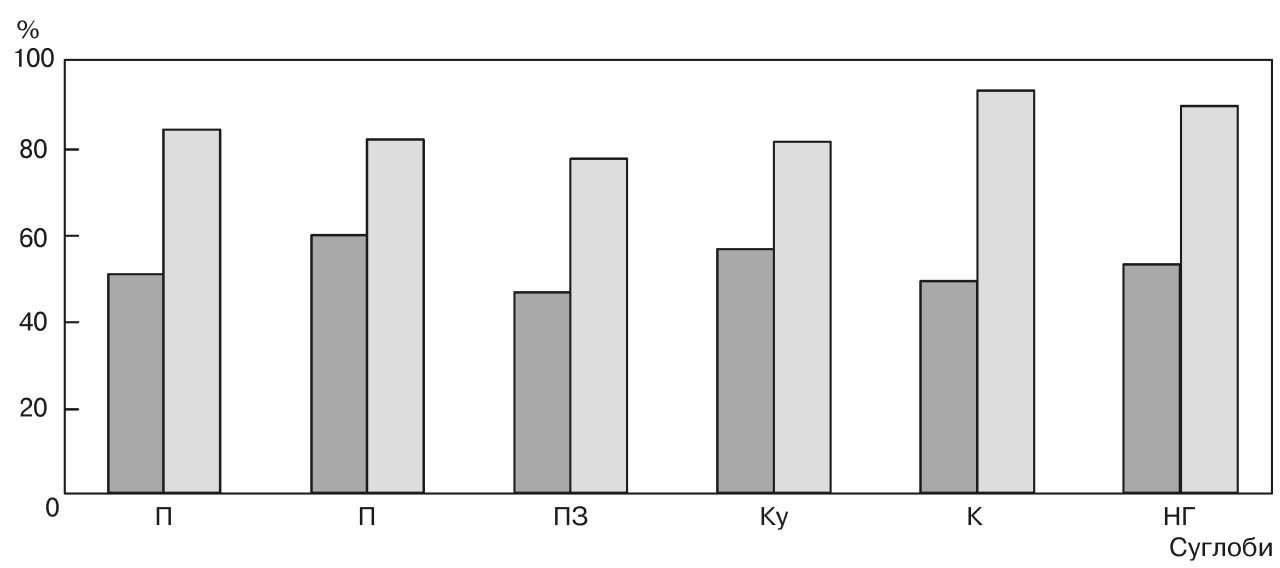

Рисунок 3 - Гоніометричні показники до курсу ( $\square)$ та після $(\square)$ курсу ФР

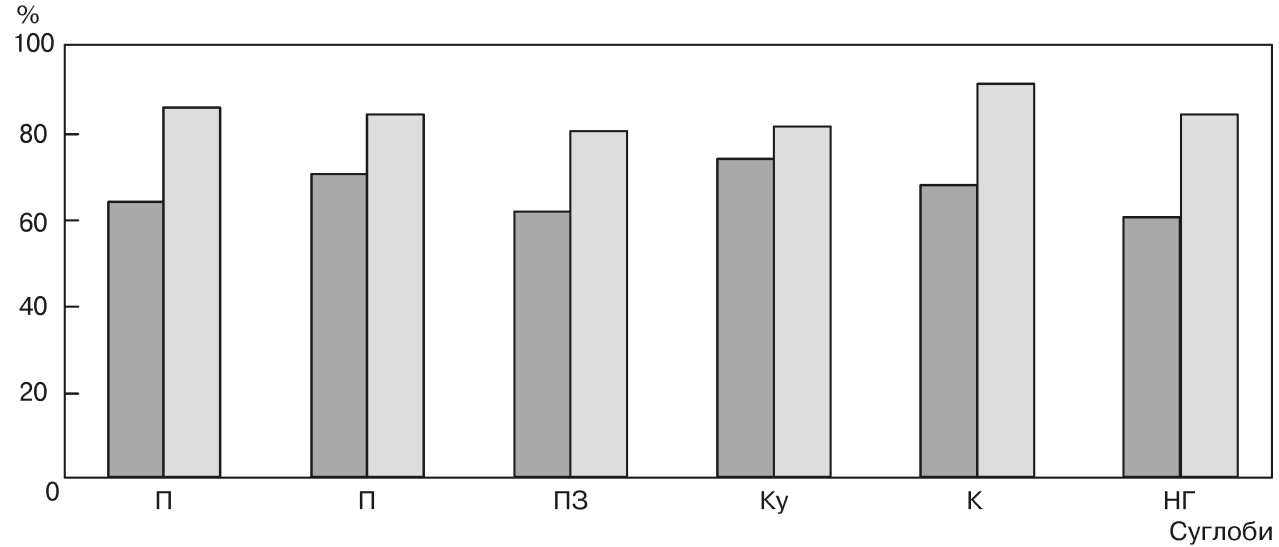

Рисунок 4 - Показники ММТ до курсу $(\square)$ та після курсу $(\square)$ ФP

\section{Література}

1. Бойчук $T$. Основи діагностичних досліджень у фізичній реабілітації: навч. посіб. для студентів вищих навчальних закладів / Т. Бойчук, М. Голубєва, О. Левандовський, Л. Войчишин. - Л.: ЗУКЦ, 2014. - 240 с.

2. Грін С. О. Аналіз та методи визначення ефективності роботи відділення фізичної реабілітації Українського державного медико-соціального центру ветеранів війни / С. О. Грін// Proceedings of the 6th International Academic Congress "Science, Education and Culture in Eurasia and Africa» (France, Paris, 23-25 March 2016). - Paris University Press, 2016. - C. 401406 .

3. Жарова І. О. Застосування заходів фізичної реабілітації у осіб з вогнепальними переломами надп'ятково-гомілкового суглоба та кісток гомілки на санаторно-курортному етапі лікування / І. О. Жарова, С. О. Грін // Теорія і методика фіз. виховання і спорту. - № 2. - 2017. - С. 49-53.

4. Іващенко С. Н. Особливості побудови фазової моделі фізичної реабілітації військовослужбовців, що постраждали внаслідок бойових дій / С. Н. Іващенко, Л. Я. Шахліна, О. Б. Лазарєва // Наук. часопис Нац. пед. ун-ту ім. М. П. Драгоманова. Сер. 15. - 2016. - С. 63-67.

5. Марцинкевич Е. Д. Здоровье и физическая реабилитация военнослужащих / Е. Д. Марцинкевич - СПб.: Воен. ин-т физ. культуры, НИЦ «Арктика» ДВО РАН, 2011. - 482 с.

6. Никаноров А. К. Физическая реабилитация больных с множественными травмами диафизов бедра и голени / А. К. Никаноров // Педагогіка, психологія та медико-біол. пробл. фіз. виховання і спорту / за ред. проф. С. С. Єрмакова. - Х.: ХДАДМ (ХХПІ). - № 1. - 2006. - С. 129 131.

7. Остроушко О. Д. Обстеження функціональних можливостей опорно-рухового апарату для визначення ефективності реабілітаційних заходів при вогнепальних ураженнях плечового суглоба / О.Д.Остроушко, Ю. А. Попадюха // Наук. часопис Нац. пед. ун-ту ім. М. П. Драгоманова.

\section{References}

1. Boychuk, T. Holubyeva, M., Levandovs'kyy, O., Voychyshyn, L. (2014). Osnovy diahnostychnykh doslidzhen u fizychniy reabilitatsiyi [Fundamentals of diagnostic tests in physical rehabilitation]. Lviv: ZUKTS [in Ukrainian].

2. Hrin, S.O. (2016). Analiz ta metody vyznachennya efektyvnosti roboty viddilennya fizychnoyi reabilitatsiyi Ukrayinskoho derzhavnoho medykosotsialnoho tsentra veteraniv viyny [Analysis methods for determining the effectiveness of the department of physical rehabilitation of Ukrainian State Medical and Social Center for War Veterans]. Proceedings from Science, Education and Culture in Eurasia and Africa: 6th International Academic Congress (France, Paris, 23-25 March 2016). Paris University Press, $401-406$ [in Ukrainian].

3. Zharova, I.O., Green, S.O. (2017). Zastosuvannya zakhodiv fizychnoyi reabilitatsiyi u osib z vohnepalnymy perelomamy nadpyatkovo-homilkovoho suhloba ta kistok homilky na sanatorno-kurortnomu etapi likuvannya [Application of measures of physical rehabilitation in persons with inflammatory fractures of the adnexal-tibia joint and leg bones at the spa-resort stage of treatment]. Teoriya i metodyka fizychnoho vykhovannya i sportu - Theory and methods of physical education and sport, 2, 49-53 [in Ukrainian].

4. Ivashchenko, S.N., Shakhlina, L.Ya., Lazaryeva, O.B. (2016). Osoblyvosti pobudovy fazovoyi modeli fizychnoyi reabilitatsiyi viyskovosluzhbovtsiv, shcho postrazhdaly vnaslidok boyovykh diy [Phase Model for Physical Rehabilitation of Servicemen Affected as a Result of Combat Activities]. Naukovyy chasopys Natsional'noho pedahohichnoho universytetu imeni M. P. Drahomanova - Scientific journal of the National Pedagogical University named after M.P. Dragomanov, Series 15, $63-67$ [in Ukrainian].

5. Marcinkevich, E.D. (2011). Zdorov'ye i fizicheskaya reabilitatsiya voyennosluzhashchikh [Health and physical rehabilitation of servicemen]. Sankt Peterburg: Voyenniy institut fizicheskoy kul'tury, NITS «Arktika» DVO RAN [in Russian]. 
Сер. 15: Науково-педагогічні проблеми фрізичної культури (фізична культура і спорт). - К.: Вид-во НПУ ім. М. П. Драгоманова. - 2016.- С. 135-138

8. Пархотик И. И. Физическая реабилитация при травмах верхних конечностей / И. И. Пархотик. - К : Олимп. лит., 2007. - 282 с.

9. Попадюха Ю. А. Технічні засоби для відновлення рухових функцій верхніх кінцівок людини / Ю. А. Попадюха, Н. І. Пеценко // Наук. часопис Нац. пед. ун-ту ім. М. П. Драгоманова. Сер. 5: Педагогічні науки: реалії та перспективи. - 2009. - Вип. 14. - С. 165-168.

10. Пояснювальна записка до проекту закону України № 4458 від 15.04.2016 Про попередження інвалідності та систему реабілітації в Україні [Електронний ресурс]. - Режим доступу : http://search.ligazakon. ua/l_doc2.nsf/link1/GH3FU00A.html

11. Раад Ахма. Фізична реабілітація після розривів ахіллового сухожилля: огляд сучасних підходів / Ахма Раад, В. Вітомський, О. Лазарєва, М. Вітомська // Слобожан. наук.-спорт. вісн. - 2017. - № 2. - С. 78-86.

12. Усик С. Ф. Особенности этапной санаторно-курортной реабилитации раненых в конечности в современных условиях: дис. ... канд. мед. наук / С. Ф. Усик. - М., 2003. - 164 с.

13. Kendall F. Muscles: Testing and Function, with Posture and Pain / F. Kendall. - Lippincott Williams \& Wilkins, 2005. - 480 p.

14. Ofer $\mathrm{G}$. Injuries characteristics of IDF soldiers in second Lebanon war / G. Ofer, W. Aviram, D. Micky et al. // JIMM. - 2007. - P. 3-6.

15. Yuval R. Injuries characteristics of IDF soldiers in operation cast lead / R. Yuval, H. Eran, D. Salah // JIMM. - 2009. - P. 95-98.
6. Nikanorov, A.K. (2006). Fyzycheskaya reabylytatsyya bolnykh s mnozhestvennymy travmamy dyafyzov bedra y holeny [Physical rehabilitation of patients with multiple injuries of the hip and thigh diaphyses]. S.S. Yermakov (Ed.) Pedahohika, psykholohiya ta medyko-biolohichni problemy fizychnoho vykhovannya $i$ sportu - Pedagogy, psychology and medicalbiological problems of physical education and sports, 1, 129-131 [in Russian].

7. Ostroushko, O.D., Popadyuha, Y.A. (2016). Obstezhennya funktsionalnykh mozhlyvostey oporno-rukhovoho aparatu dlya vyznachennya efektyvnosti reabilitatsiynykh zakhodiv pry vohnepalnykh urazhennyakh plechovoho suhloba [Survey functionality of the musculoskeletal system to determine the effectiveness of rehabilitation with gunshot injuries of the shoulder joint]. Naukovyy chasopys Natsional'noho pedahohichnoho universytetu imeni M. P. Drahomanova - Scientific journal of the National Pedagogical University named after M.P. Dragomanov; Ser. 15: Naukovo-pedahohichni problemy fizychnoyi kul'tury (fizychna kul'tura i sport) - Ser. 15: Scientific and pedagogical problems of physical culture (physical culture and sport), 15, 135-138 [in Ukrainian].

8. Parkhotik, I.I. (2007). Fizicheskaya reabilitatsiya pri travmakh verkhnikh konechnostey [Physical rehabilitation in injuries of the upper limbs]. Kiev: Olimpiyskaya literatura [in Russian].

9. Popadyukha, Y.A., Petsenko, N.I. (2009). Tekhnichni zasoby dlya vidnovlennya rukhovykh funktsiy verkhnikh kintsivok lyudyny [Technical means for restoration of motor functions of the upper limbs of a person]. Naukovyy chasopys Natsional'noho pedahohichnoho universytetu imeni M. P. Drahomanova - Scientific journal of the National Pedagogical University named after M.P. Dragomanov; Ser. 5: Pedahohichni nauky: realiyi ta perspektyvy - Ser. 5: Pedagogical sciences: realities and perspectives, 14 165-168 [in Ukrainian].

10. The explanatory note to the draft law of Ukraine N 4458 from 04.15.2016, on the prevention of disability and rehabilitation system in Ukraine. Available at : http://search.ligazakon.ua/l_doc2.nsf/link1/GH3FU00A.html [in Ukrainian].

11. Ra'ad, Ahma, Vitovskii, V., Lazareva, O., Vitomska, M. (2017). Fizychna reabilitatsiya pislya rozryviv akhillovoho sukhozhyllya: ohlyad suchasnykh pidkhodiv [Physical rehabilitation after Achilles tendon ruptures: an overview of modern approaches]. Slobozhans'kyy naukovo-sportyvnyy visnyk Slobozhansky scientific and sports newsletter, 2, 78-86 [in Ukrainian].

12. Usik, S.F. (2003). Osobennosti etapnoy sanatorno-kurortnoy reabilitatsii ranenykh $\mathrm{v}$ konechnosti $\mathrm{v}$ sovremennykh usloviyakh [Features of the stage sanatorium-and-spa rehabilitation of the wounded in the limb in modern conditions]. Doctor's thesis. Moscow [in Russian].

13. Kendall, F. (2005). Muscles: Testing and function, with posture and pain. Lippincott Williams \& Wilkins.

14. Ofer, G., Aviram, W., Micky, D., Aviv, K., Michael, Y., Ofir, C., Ronene, G., Oren, F., Nahman, A., Gil, H., Amir, B. (2007). Injuries characteristics of IDF soldiers in second Lebanon war. JIMM, 4, 3-6.

15. Yuval, R., Eran, H., Salah, D., Micha, K., Avraham, D., Carmi, A., Gil, H. (2009). Injuries characteristics of IDF soldiers in operation cast lead. JIMM 6, 95-98

Надійшла 11.01.2018 